\title{
ENHANCHING MALAYSIAN GRADUATE EMPLOYABILITY SKILLS: QUALITY FUNCTION DEPLOYMENT APPROACH
}

\author{
Mohamad Shukri Abdul Hamid* \\ School of Quantitative Sciences \\ Universiti Utara Malaysia \\ 06010 Sintok, Kedah, Malaysia \\ E-mail: mohdshukri@uum.edu.my \\ Rafikul Islam \\ Department of Business Administration \\ Kulliyyah of Economics and Management Sciences \\ International Islamic University Malaysia \\ Jalan Gombak, 53100 Kuala Lumpur, Malaysia \\ E-mail: rislam@iium.edu.my \\ Noor Hazilah Abd Manaf \\ Department of Business Administration \\ Kulliyyah of Economics and Management Sciences \\ International Islamic University Malaysia \\ Jalan Gombak, 53100 Kuala Lumpur, Malaysia \\ E-mail: hazilah@iium.edu.my
}

\begin{abstract}
In the challenging economic world, employers are looking for graduates employees who are able drive organization to compete successfully in the market. Graduates should equip themselves with relevant employability skill as needed by the recent employers. Besides that, higher education institutions must evaluate the effectiveness of employability skills development approaches on graduates' employability skills. The main objectives of this study are to identify the important of Malaysian graduates' employability skills and to identify the most effective employability skills development approaches. This study used Quality Function Deployment method to evaluate the effectiveness of the employability skills development approaches. In general, the result of this study shows that employers placed highest important on ability of the graduates to speak fluently in English and then followed by the ability of the graduates to write effectively in English and the ability of the graduates to think critically. Meanwhile, the final result of the Quality Function Deployment shows that work integrated learning is most effective employability skills development approach with a percentage priority of 31 percent. The next most effective approaches are stand-alone subject model with 19 percent and then followed by academic support programme, embedded subject model, nonacademic support programme and campus life activities.
\end{abstract}

Key Words: Employability skills, Quality Function Deployment (QFD), Analytic Network Process (ANP), Extreme Pairwise Comparison with Median Rank (EPCMR)

\subsection{Introduction}

The fundamental purposes of total quality management (TQM) is to provide services that meet or exceed the expectations of the customers, and to bridge the gap between the expectations of customers and the capabilities of the organizations to fulfil these expectations. Customer requirements are sometimes misunderstood because the language used by the customers is often vague. To overcome

\footnotetext{
${ }^{*}$ Corresponding author
} 
this deficiency, one of the TQM tools, known as quality function deployment (QFD), has been widely used (Chan \& Wu, 2002). QFD was introduced by Professor Yoji Akao who described both the terminology and the procedure in his article published in 1972. According to Logothetis (2004), QFD is one of the TQM tools that integrate the TQM philosophy into new product development. The fundamental idea of QFD is to translate the voice of the customer or customer requirements into the quality of the product and/or quality of the service beginning at the design phase. In other words, this tool is very helpful for an organization to identify the customers, their wants and how to fulfil their wants. In order to understand the QFD process, it is essential to understand how QFD fits into the product development cycle in terms of timing, performance evaluation and resource commitment.

\subsection{Quality Function Deployment}

There are four phases in the product development cycle in the QFD process, namely product planning, product design, process planning and process control, as shown in Figure 1. The product concept planning phase (phase one) involves customer perceptions and market research to identify customer requirements, competitive opportunity, product measurement, competing product measure and technical requirements to meet each of the customer requirements. In this phase, getting the true data from the customer is important to ensure the success of the QFD process.

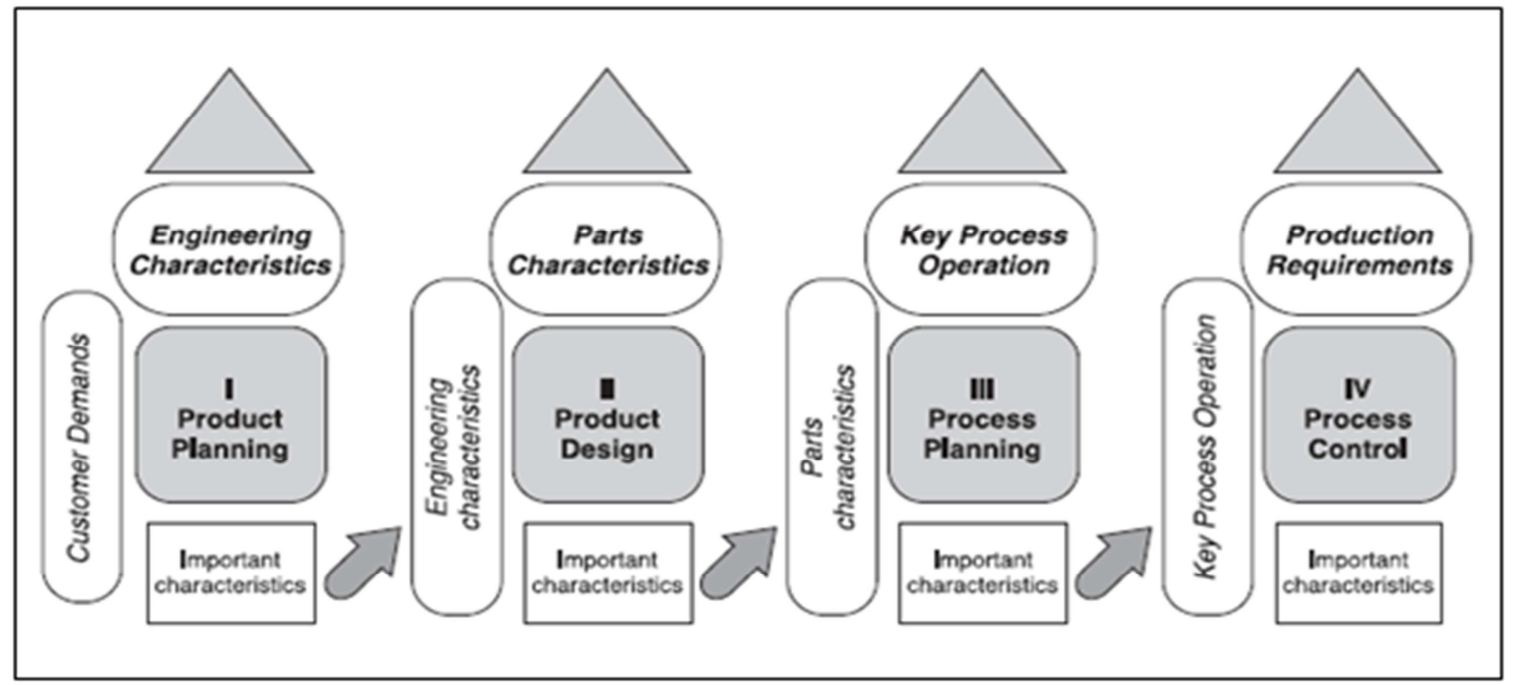

Figure 1: Product development cycle in QFD

In the product design phase (phase two), design specifications are converted into product concepts, product development and component specifications. In this phase, prototypes are built and tested. In the process planning phase (phase three), the manufacturing process and production tools are designed based on the product specification in phase two. Pilot runs for the manufacturing process and production tolls are made to ascertain the product's manufacturability levels and production standards. When the problems identified in the pilot run have been resolved, production requirements for the product are developed (phase four). In this phase, customer feedback is important for the improvement of the future products.

There are many tools to aid in developing and implementing each phase of the QFD process. The House of Quality (HOQ) matrix is widely used in association with QFD and is most often the foundation of the product planning phase (Day, 1993; ReVelle et al., 1998). The HOQ is a product planning matrix which generally consists of customer requirements, technical requirements, correlation matrix between customer and technical requirements, customer priority, competitive analysis and technical importance rating (Eureka \& Ryan, 1994). As Figure 2 shows, the left room of the HOQ lists the customer needs or requirements and is called the "Whats." "Whats" are phrases that customers use to describe their needs. The needs are translated into corresponding "Hows," as shown in the upper room below the roof. "Hows" are a structured set of relevant and measurable product characteristics. The function of the "Hows" is to translate the "Whats" into terms that are measurable. 
After the "Whats" and the "Hows" have been identified, the next step is to specify their correlation in the body of the correlation matrix of the HOQ. The correlation matrix shows the QFD team's perceptions of correlation between "Hows" and "Whats." Meanwhile, the roof of the HOQ shows the inter-correlation among technical requirements. This is used to identify where technical requirements support or impede each other in the product design. The right room of the HOQ shows the customer's perception of their priority, the company's performance and the competitors' performance in meeting these requirements. The bottom room of the HOQ is where technical importance ratings that represent the priorities assigned to the technical requirements are placed. The framework also shows a set of target values for each technical requirement to be met by the new design, which are linked back to the demands of the customers.

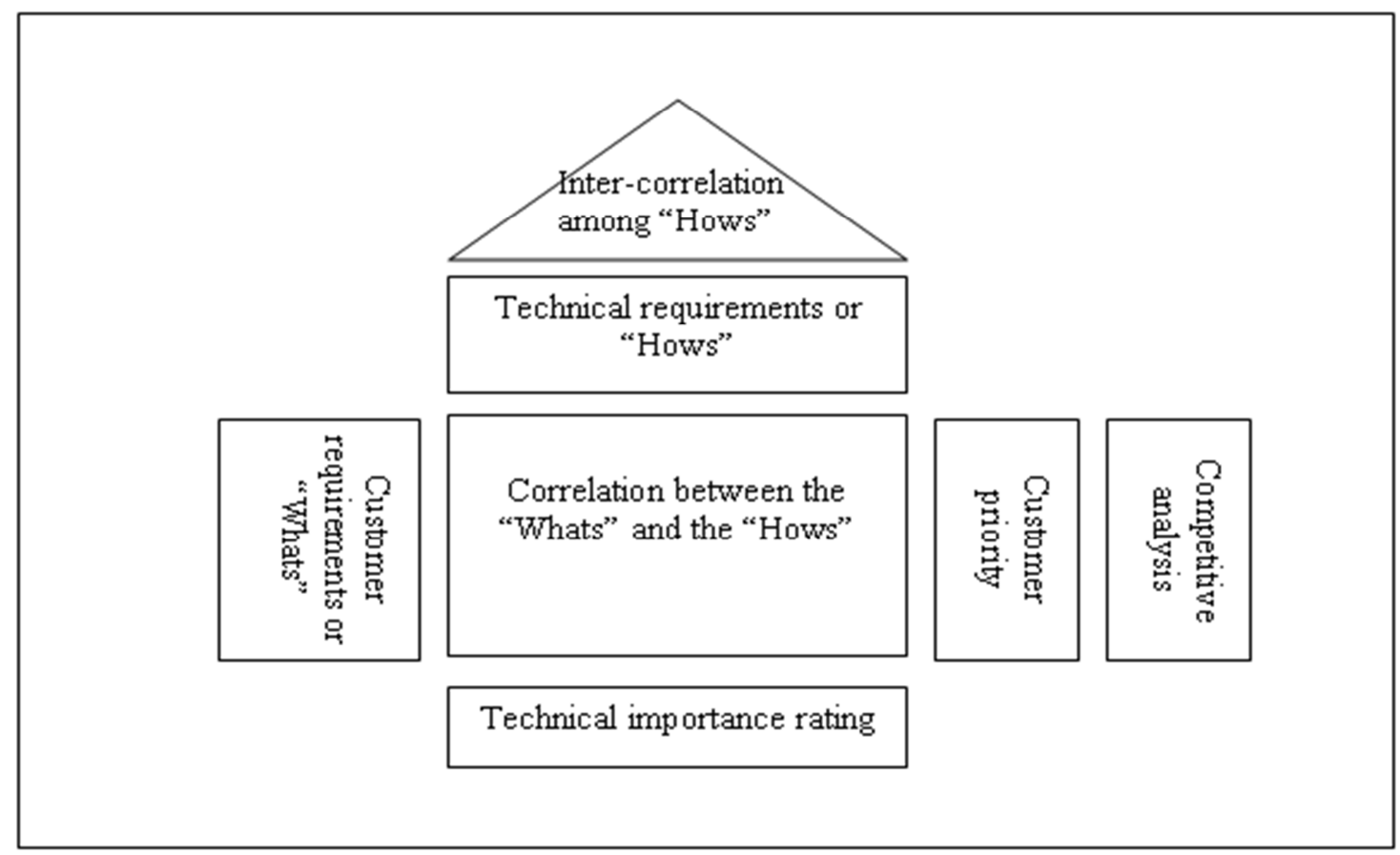

Figure 2: General framework of a House of quality

Akao (1990) stated that QFD is an approach to product design and attempts to translate the voice of the customer into the language of the engineer, and subsequently, into design characteristics. During the development phase, the QFD process transforms the design feature into part features. In the operation stage, the crucial part is to deploy the customer requirements and expectations into the production process. The core principle of this concept is a systematic transformation of customer requirements and expectations into measurable products and process parameters. According to Akao and Mazur (2003), the purpose of the QFD approach is to ensure that customer requirements are deployed into the product design, production process and delivery of a new product, and also to improve the existing product.

Lockamy III and Khurana (1995) stated that QFD consists of two components, quality and function, which are deployed in the design process. The "quality deployment" component transforms the customer requirements into the design process. This process ensures that the design and quality of the product are consistent with the customer's requirements. On the other hand, "the function deployment" component involves collecting inputs from different departments and units, and transforms the design into the manufacturing process. QFD provides a systematic means of translating customer requirements into relevant technical requirements and actions throughout each stage of the product life cycle, from marketing strategies, planning and product design, prototype evaluation, process development and production, and sale to the eventual users (Gonzalez et al., 2004). QFD should be implemented in the early phase of the product development cycle to ensure that all major design conflicts and problems are solved before production takes place (Bicknell \& Bicknell, 1995). 
This aims to satisfy the customer needs by ensuring quality at each stage of the product development process.

As stated by Shigeru Mizuno and Yogi Akao from the Tokyo Institute of Technology in the 1960s, the earliest use of QFD can be traced back to Mitsubishi Heavy Industries Limited in the Kobe Shipyard, Japan in 1972. In Japanese "deployment" refers to an extended involvement or broadening of various activities. QFD in Japanese is "Hin shitsu kino ten kai." Lockamy III and Khurana (1995, p. 74) provide the following translation; "hin shitsu" means quality or feature or attribute, "ki no" means function or mechanism and "ten kai" means deployment, diffusion, development or evolution. QFD is defined by Dr Yoji Akao (Mallon \& Mulligan, 1993, p.517) as:

"Converting the customers' demands into quality characteristics and developing a design quality for the finished product by systematically deploying the relationships between the demands and characteristics, starting with the quality of each part and process. The overall quality of the product will be formed through this network of relationships".

The Japanese corporate sector considers QFD an important tool which promotes awareness about the need to focus on customer requirements and encourages company-wide responsibility and commitment towards achieving quality standards consistent with customer expectations and the companies' own aspirations (Zairi \& Youssef, 1995). The QFD methodology assures with a high degree of confidence that a company will be able to design and develop its new products to maximize customer satisfaction using the right resources (Kumar et al., 2006). According to Zairi and Youssef (1995), QFD is an ideal tool to move away from "we know best what the customer wants" to a new culture of "let's hear the voice of the customer." In a sense, it enables the organization to become proactive rather than being reactive by waiting for customer complaints.

QFD is a structured approach to identify customers, understand their needs, and provide customer satisfaction by ensuring their needs are met (Han et al., 2001). In other words, it is to ensure that the characteristics of a product are consistent with the customer requirements. In addition, QFD can help an organization to plan for the effective application of its quality tools by directing the application towards issues of importance to customers (Lee et al., 2000). QFD can help companies make the key tradeoffs between what the customer wants and what the company can actually afford to build. However, resources may be limited, and addressing all the customer requirements may not be economically feasible. By being focused, the QFD team can exert efforts on what will satisfy the customer most, and consequently, less time will be spent on redesign and modifications of the product/process. This process helps companies move away from an inspection-based approach to building quality into products. QFD replaces the inconsistent, intuitive decision making process with a structured and systematic approach of prioritizing customer requirements, and supports the "trade-off" decisions that will have the greatest impact on satisfying the customers (Lockamy III \& Khurana, 1995; Bouchereau \& Rowlands, 2000).

The house of quality also provides important information to help an organization prioritize activities that need to be implemented. In addition, it helps organization to benchmark of the products/services with their competitors so that improvements can be made in the previous stage of design. Its power as a benchmarking tool in various applications and studies has shown a wide range of benefits for QFD (Zairi \& Youssef, 1995). Other advantages of using QFD include increased market share and higher profits (Cohen, 1995). Griffin and Hauser (1993) concluded that QFD leads to a reduction in the number of design changes, lower start-up costs, shorter design cycles, fewer warranty claims, improved internal communication and increased sales. With the customer as the starting point, QFD reduces cycle time by aiding producers to design products right the first time by focusing on customer requirements (Zairi \& Youssef, 1995). The major features of QFD are to seek out the voice of the customer and translate that into appropriate technical requirements for each stage of product development (Abdul Rahman et al., 1999). QFD is also a communication tool, which helps engineers synchronize the marketing and production departments, and also plays a leading role in new product development (Akao \& Mazur, 2003). QFD promotes teamwork and encourages cross-functional 
inputs from various departments, including marketing, development, manufacturing and distribution, and also translates customer voices into product design.

\subsection{An example of application of QFD in Malaysian Higher education}

\section{Step 1: Identify and prioritize customer requirements}

The researchers have conducted extensive literature reviews to identify graduates' employability skills. Therefore, 49 attributes of graduates employability skills were discovered, which are grouped into six dimensions namely interpersonal skills, computing skills, enterprise and entrepreneurial skills, communication skills, thinking skills and management skills. Importance-performance analysis (IPA) was conducted to map the attributes into four quadrants namely areas to improve, keep up the good work, low priority and possible waste of resources. Based on the IPA map, 13 graduates' employability skills fell in the areas to improve, indicating that these attributes are perceived as important by employers, but satisfaction levels on that skills are low; consequently, more attention needs to be paid to these skills. These attributes are shown in Table 1:

Table 1. List of graduates' employability skills

\begin{tabular}{lll}
\hline & Graduates' employability skills & \multicolumn{1}{c}{ Short form } \\
\hline A & Ability to write effectively in English & Writing in English \\
B Ability to speak fluently in English & Speaking in English \\
C Ability to recognize and analyse problems & Problem-solving \\
D Ability to think critically & Critical thinking \\
E Ability to express own ideas clearly, effectively and with & $\begin{array}{l}\text { Confidence in expressing } \\
\end{array}$ & ideas \\
F $\quad$ Ability to explain, analyse and evaluate data/information & Information management \\
G Ability to generate creative ideas & Creative ideas \\
H Ability to think out of the box & Think out of the box \\
I Ability to encourage and motivate others & Motivation \\
J Ability to do presentations of a project effectively & Presentation skills \\
K Ability to make logical conclusion by analysing relevant & Decision-making skills \\
& information & \\
L Ability to manage others & Leadership \\
M Ability to search and manage the relevant information from & Information searching \\
& \\
\hline
\end{tabular}

The overall mean importance of the graduates' employability skills were compared to each other using extreme pairwise comparison to determine the important weights of these skills. For instance, if the mean score for skill A is greater than the mean score for skill B, " 1 " is given. Conversely, ' -1 ' is given if the mean score for skill A is less than the mean score for skill B. If the mean scores for skill $\mathrm{A}$ and $\mathrm{B}$ are judged to be almost equal, a score of " 0 " is assigned. Total scores for each skill are calculated and ranked in decreasing order (high score means high importance). Table 2 shows the method of extreme pairwise comparisons to compute the weight of graduates' employability skills.

The next step involved using the extreme pairwise comparison with median rank (EPCMR) to determine an importance weighting of each employability skill, using the formula below:

$\hat{F}(X)=\frac{r_{i}-0.3}{n+0.4}$, where; $n=$ number of the skills; $r_{i}=$ rank of the $i$-th skill.

Table 3 shows the absolute and normalized weights of the graduates' employability skills. Refer to the Table 3, the most important skills are defined as the ability of the graduates to converse fluently in English and the ability of the graduates to write in English. This result was supported by the survey conducted by the Malaysian Employers Federation (MEF), which showed that English communication skill is the most important trait employers look for in recruiting new graduates (Azian 
\& Mun, 2011). On the other hand, the least important skill, as defined by employers, was the ability of the graduates to search and manage relevant information from various sources". 
Table 2. Extreme pairwise comparison to compute the weight of graduates' employability skills

\begin{tabular}{|c|c|c|c|c|c|c|c|c|c|c|c|c|c|c|c|}
\hline Employability Skills & $\mathrm{A}$ & $\mathrm{B}$ & $\mathrm{C}$ & $\mathrm{D}$ & $E$ & $\mathrm{~F}$ & $\mathrm{G}$ & $\mathrm{H}$ & $\mathrm{I}$ & $\mathrm{J}$ & $\mathrm{K}$ & $\mathrm{L}$ & $\mathrm{M}$ & Total & Rank \\
\hline A. Writing in English & 0 & 1 & 1 & 1 & 1 & 1 & 1 & 1 & 1 & 1 & 1 & 1 & 1 & 12 & 13 \\
\hline B. Speaking in English & -1 & 0 & 1 & 1 & 1 & 1 & 1 & 1 & 1 & 1 & 1 & 1 & 1 & 10 & 12 \\
\hline C. Problem-solving skills & -1 & -1 & 0 & 1 & 1 & 1 & 1 & 1 & 1 & 1 & 1 & 1 & 1 & 8 & 11 \\
\hline D. Critical thinking & -1 & -1 & -1 & 0 & 1 & 1 & 1 & 1 & 1 & 1 & 1 & 1 & 1 & 6 & 10 \\
\hline E. Confidence in expressing ideas & -1 & -1 & -1 & -1 & 0 & 1 & 1 & 1 & 1 & 1 & 1 & 1 & 1 & 4 & 9 \\
\hline F. Information management & -1 & -1 & -1 & -1 & -1 & 0 & 1 & 1 & 1 & 1 & 1 & 1 & 1 & 2 & 8 \\
\hline G. Creative ideas & -1 & -1 & -1 & -1 & -1 & -1 & 0 & 1 & 1 & 1 & 1 & 1 & 1 & 0 & 7 \\
\hline H. Think out of the box & -1 & -1 & -1 & -1 & -1 & -1 & -1 & 0 & 1 & 1 & 1 & 1 & 1 & -2 & 6 \\
\hline I. Motivation & -1 & -1 & -1 & -1 & -1 & -1 & -1 & -1 & 0 & 0 & 0 & 1 & 1 & -6 & 3 \\
\hline J. Presentation skills & -1 & -1 & -1 & -1 & -1 & -1 & -1 & -1 & 0 & 0 & 0 & 1 & 1 & -6 & 3 \\
\hline K. Decision-making skills & -1 & -1 & -1 & -1 & -1 & -1 & -1 & -1 & 0 & 0 & 0 & 1 & 1 & -6 & 3 \\
\hline L. Leadership & -1 & -1 & -1 & -1 & -1 & -1 & -1 & -1 & -1 & -1 & -1 & 0 & 1 & -10 & 2 \\
\hline M. Information searching & -1 & -1 & -1 & -1 & -1 & -1 & -1 & -1 & -1 & -1 & -1 & -1 & 0 & -12 & 1 \\
\hline
\end{tabular}

Note: The rank is in decreasing order. 
Table 3. Absolute and normalize weights of employability skills

\begin{tabular}{lccc}
\hline \multicolumn{1}{c}{ Employability Skills } & Rank & Absolute & Normalize \\
\hline A. Writing in English & 13 & 0.9478 & 0.1458 \\
B. Speaking in English & 12 & 0.8731 & 0.1343 \\
C. Problem-solving skills & 11 & 0.7985 & 0.1228 \\
D. Critical thinking & 10 & 0.7239 & 0.1114 \\
E. Confidence in express ideas & 9 & 0.6493 & 0.0999 \\
F. Information management & 8 & 0.5746 & 0.0884 \\
G. Creative ideas & 7 & 0.5000 & 0.0769 \\
H. Think out of the box & 6 & 0.4254 & 0.0654 \\
I. Motivation & 3 & 0.2761 & 0.0425 \\
J. Presentation skills & 3 & 0.2761 & 0.0425 \\
K. Decision-making skills & 3 & 0.2761 & 0.0425 \\
L. Leadership & 2 & 0.1269 & 0.0195 \\
M. Information searching & 1 & 0.0522 & 0.0080 \\
\hline
\end{tabular}

Step 2: identify technical requirements

In stage two, based on soft skills development module to Malaysian higher education institutions, a list of employability skills development approaches that are commonly used in teaching and learning processes were identified (MOHE, 2006). The lists of these approaches and their definitions are provided in Table 4.

Table 4. Employability skills development approaches

\section{Attributes}

(1) Embedded subject model

(2) Stand-alone subject model

(3) Academic support programmes

(4) Non-academic support programmes

(5) Campus life activities
Embedding the soft skills in the teaching and learning activities across the curriculum (e.g. integrated into core subject such as mathematics, statistics, economics, etc).

Develop soft skills through specific courses that are carefully planned for this purpose (e.g. English language, entrepreneurship, Islamic and Asian Civilisation (TITAS), etc).

Involve programmes and activities that are created, developed and used to support soft skills either directly or indirectly that are associated with academic matters (e.g. learning skills programme, English language support programme, etc).

Involve programmes and activities that are created, developed and used to support soft skills either directly or indirectly that are not related to academic matters but more of personality and professional development of the students (e.g. PALAPES, SUKSIS, etc).

Students' life in university residences and surrounding campus (e.g. programmes and activities on soft skills development). 
(6) Work-integrated learning Form of learning whereby periods of study are
alternated with periods of related work in business,
industry or government agency. In this way, students
are given the opportunity to effectively integrate the
theory of the classroom with the practice and the
responsibility of the workplace (e.g. industrial/
practical training).

Step 3: Relate customer requirements to technical requirements

In stage three, the effect of different approaches in attaining the desired results was assessed using Extreme Pairwise Comparison with Median Rank (EPCMR). Fifty lecturers were chosen to participate in determining the degree of importance in the pairwise comparison process. They were provided with a set of questionnaires and were explained the process of making pairwise comparisons. The respondents were asked to make pairwise comparisons based on their teaching experience in general, but not on a specific subject. Using the Super Decision Software version 2.0.6, Eigenvalues were calculated as shown in Table 5. The components of the Eigenvectors indicated a relative importance of the employability skills development approaches in accomplishing each of the graduates' employability skills, and then were aggregated to achieve a set of global weights.

\section{Step 4: Identify the relationships between technical requirements in the roof of the house}

In stage four, Analytic Network Process (ANP) was used to assess the inter-correlation among employability skills development approaches at the roof of the HOQ. The employability skills development approaches were ranked by pairwise comparisons using Super Decision Software. Table 6 shows weighted supermatrix that was produced through normalization of the ANP matrix. Afterwards, a limit supermatrix was generated by multiplying the weighted supermatrix by itself and produced synthesized overall values. Table 7 shows the limit supermatrix and also known as technical importance rating in QFD.

\section{Step 5: Prioritize and determine which technical requirements to deploy}

The final step was the calculation of the overall importance ratings (OIR). The procedure started by multiplying the results found in stage one, three and four. The importance weight of graduates' employability skills was found in stage one, the correlation strength between employability skills development approaches and graduates' employability skills was found in stage three, and the degree of importance of employability skills development approaches was found in stage four.

Table 8 shows the final house of quality. The results show that the most effective employability skills development approach to improve employability skills of graduate is work-integrated learning, having a priority of 31 percent. Having a high priority indicates a need to improve this approach in future action plans. The next most effective approaches are stand alone subject models (19\%), academic support programmes $(17 \%)$ and embedded subject models $(15 \%)$. In contrast, the least effective development approaches are non-academic support programmes (7\%) and campus life activities (13\%). This study shows that universities should give priority to providing students with real life working environments and hands-on learning through industrial/practical training. Perhaps via more rigorous internship programmes, students will be able to relate the theories and practices when they join the workforce later. 
Table 5. The QFD matrix

\begin{tabular}{|c|c|c|c|c|c|c|}
\hline & $\begin{array}{c}\text { Embedded } \\
\text { subject } \\
\text { model }\end{array}$ & $\begin{array}{c}\text { Stand alone } \\
\text { subject } \\
\text { model }\end{array}$ & $\begin{array}{c}\text { Academic } \\
\text { support } \\
\text { programme }\end{array}$ & $\begin{array}{c}\text { Nonacademic } \\
\text { support } \\
\text { programme }\end{array}$ & $\begin{array}{c}\text { Campus } \\
\text { life } \\
\text { activities }\end{array}$ & $\begin{array}{c}\text { Work } \\
\text { integrated } \\
\text { learning }\end{array}$ \\
\hline B. Speaking in English & 0.0365 & 0.2969 & 0.1927 & 0.1146 & 0.1146 & 0.2448 \\
\hline C. Problem-solving skills & 0.2448 & 0.0885 & 0.1667 & 0.0365 & 0.1667 & 0.2969 \\
\hline D. Critical thinking & 0.2448 & 0.2448 & 0.0885 & 0.1406 & 0.0365 & 0.2448 \\
\hline G. Creative ideas & 0.0625 & 0.1667 & 0.1667 & 0.0625 & 0.2969 & 0.2448 \\
\hline H. Think out of the box & 0.0365 & 0.1406 & 0.0885 & 0.2448 & 0.2969 & 0.1927 \\
\hline I. Motivation & 0.0365 & 0.2709 & 0.1667 & 0.0885 & 0.1667 & 0.2709 \\
\hline J. Presentation skills & 0.2188 & 0.0365 & 0.1406 & 0.0885 & 0.2188 & 0.2969 \\
\hline K. Decision-making skills & 0.1346 & 0.2088 & 0.2088 & 0.1346 & 0.0265 & 0.2868 \\
\hline
\end{tabular}


Table 6. Weighted supermatrix

\begin{tabular}{|c|c|c|c|c|c|c|}
\hline Variables & $\begin{array}{c}\text { Embedded } \\
\text { subject } \\
\text { model }\end{array}$ & $\begin{array}{c}\text { Stand alone } \\
\text { subject } \\
\text { model }\end{array}$ & $\begin{array}{c}\text { Academic } \\
\text { support } \\
\text { programme }\end{array}$ & $\begin{array}{c}\text { Non-academic } \\
\text { support } \\
\text { programme } \\
\end{array}$ & $\begin{array}{l}\text { Campus } \\
\text { life } \\
\text { activities } \\
\end{array}$ & $\begin{array}{c}\text { Work- } \\
\text { integrated } \\
\text { learning } \\
\end{array}$ \\
\hline Embedded subject model & - & 0.1895 & 0.2731 & 0.1816 & 0.1383 & 0.2418 \\
\hline Stand-alone subject model & 0.2020 & - & 0.2132 & 0.2150 & 0.2038 & 0.2249 \\
\hline Academic support programme & 0.2850 & 0.2085 & - & 0.1944 & 0.1780 & 0.2028 \\
\hline Non-academic support programme & 0.0938 & 0.1721 & 0.1298 & - & 0.2603 & 0.1627 \\
\hline Campus life activities & 0.1273 & 0.1760 & 0.1572 & 0.1518 & - & 0.1678 \\
\hline Work-integrated learning & 0.2918 & 0.2539 & 0.2267 & 0.2572 & 0.2195 & - \\
\hline
\end{tabular}

Table 7. Limit supermatrix

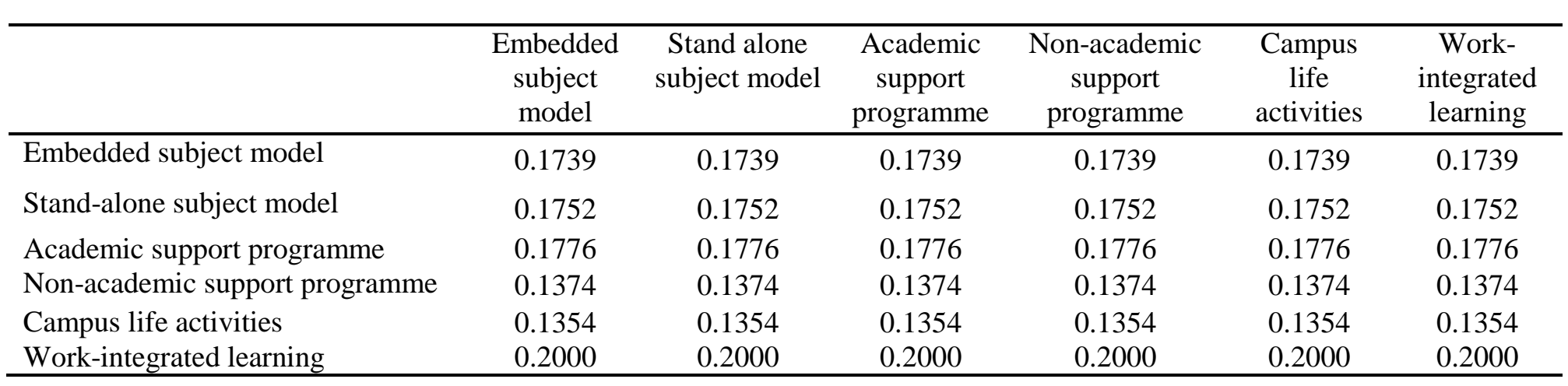


Table 8. Final house of quality

\begin{tabular}{|c|c|c|c|c|c|c|c|}
\hline 1 & 2 & 3 & 4 & 5 & 6 & 7 & 8 \\
\hline Embedded subject model & & 0.0000 & 0.1895 & 0.2731 & 0.1816 & 0.1383 & 0.2418 \\
\hline Stand-alone subject model & & 0.2020 & 0.0000 & 0.2132 & 0.2150 & 0.2038 & 0.2249 \\
\hline Academic support programme & & 0.2850 & 0.2085 & 0.0000 & 0.1944 & 0.1780 & 0.2028 \\
\hline Non-academic support programme & & 0.0938 & 0.1721 & 0.1298 & 0.0000 & 0.2603 & 0.1627 \\
\hline Campus life activities & & 0.1273 & 0.1760 & 0.1572 & 0.1518 & 0.0000 & 0.1678 \\
\hline ated leaming & & 0.2918 & 0.2539 & 0.2267 & 0.2572 & 0.2195 & 0.0000 \\
\hline & 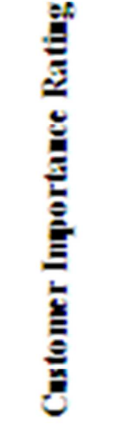 & 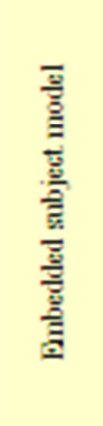 & 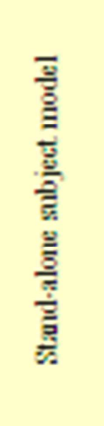 & 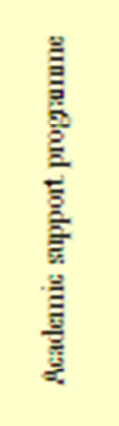 & 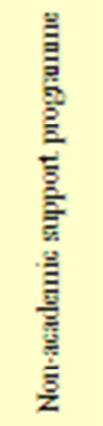 & 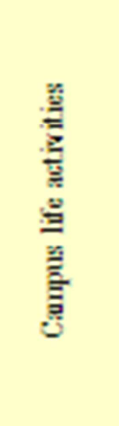 & 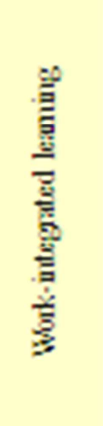 \\
\hline Technical Importance & & 0.1739 & 0.1752 & 0.1776 & 0.1374 & 0.1354 & 0.2000 \\
\hline A. Writing in English & 0.1458 & 0.1306 & 0.2760 & 0.2348 & 0.0365 & 0.0705 & 0.2508 \\
\hline B. Speaking in English & .1343 & 0.0365 & 0.2969 & 0.1927 & 0.1146 & 0.1146 & 0.2448 \\
\hline C. Problem-solving skills & .1228 & 0.2448 & 0.0885 & 0.1667 & 0.0365 & 0.1667 & 0.2969 \\
\hline D. Critical thinking & 0.1114 & 0.2448 & 0.2448 & 0.0885 & 0.1406 & 0.0365 & 0.2448 \\
\hline E. Confidence in expressing ideas & 0.0999 & 0.2188 & 0.0885 & 0.1406 & 0.0365 & 0.2188 & 0.2969 \\
\hline F. Information management & 0.0884 & 0.1927 & 0.0885 & 0.1927 & 0.0365 & 0.1927 & 0.2969 \\
\hline G. Creative ideas & 0.0769 & 0.0625 & 0.1667 & 0.1667 & 0.0625 & 0.2969 & 0.2448 \\
\hline H. Think out of the box & 0.0654 & 0.0365 & 0.1406 & 0.0885 & 0.2448 & 0.2969 & 0.1927 \\
\hline I. Motivation & 0.0425 & 0.0365 & 0.2709 & 0.1667 & 0.0885 & 0.1667 & 0.2709 \\
\hline J. Presentation skills & 0.0425 & 0.2188 & 0.0365 & 0.1406 & 0.0885 & 0.2188 & 0.2969 \\
\hline K. Decision-making skills & 0.0425 & 0.1346 & 0.2088 & 0.2088 & 0.1346 & 0.0265 & 0.2868 \\
\hline L. Leadership & 0.0195 & 0.0365 & 0.1146 & 0.1146 & 0.2448 & 0.1927 & 0.2969 \\
\hline M. Information searching & 0.0080 & 0.1927 & 0.1406 & 0.2709 & 0.0365 & 0.0885 & 0.2709 \\
\hline \multicolumn{2}{|l|}{ Overall Importance Rating (OIR) } & 0.0267 & 0.0330 & 0.03066 & 0.0104 & 0.02260 & 0.0524 \\
\hline \multirow{2}{*}{\multicolumn{2}{|c|}{$\begin{array}{l}\text { Relative } \% \\
\text { Importance }\end{array}$}} & $15 \%$ & $19 \%$ & $17 \%$ & $7 \%$ & $12 \%$ & $31 \%$ \\
\hline & & 4 & 2 & 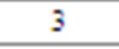 & 6 & 5 & 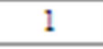 \\
\hline
\end{tabular}

\subsection{Conclusion and discussion}

The main objective of this study is to employ QFD method to evaluate the effectiveness of the employability skills development approaches in order to equip graduates with relevant employability skills. Based on the literature review, the researchers has identified 49 attributes of employability skills that were grouped in six categories namely; interpersonal skills, computing skills, management skills, communication skills, enterprise and entrepreneurial skills and thinking skills. Furthermore, based on the soft skills development module for Malaysian higher education institutions, six employability skills approaches were identified, namely; embedded subject model, stand-alone subject model, academic support programmes, non-academic support programmes, campus life activities and work integrated learning.

The result of this study shows that English language abilities are found most important skills sited by the respondents. The literature also supported that the employers are searching for a graduate that are able to communicate fluently in English and weakness in English is one of the main reasons why 
graduates have difficulty in finding a jobs. This situation is worrying because English is a compulsory subject at the primary and secondary schools in Malaysia. The situation is more critical in rural area schools. At the university level, students are required to take a few English subjects as a requirement of their graduation (i.e. English for communication, public speaking, business report writing and academic writing). Although students have been exposed to the importance of English language from primary school through university, the inefficiency of students in the English language is still a major cause of un- and underemployment. It is therefore important that English language education in Malaysia is reviewed at the roots to identify the main cause of the problem and to provide access and equal opportunity to all students.

In addition, the results QFD analysis demonstrates the importance of on-the-job training in developing graduates' employability skills. On-the-job training is a form of training whereby students were attached at a company for a period of time (normally 4 to 6 months). Through on-the-job training programmes, students are able to practice the theories and knowledge that they have learnt during their studies at university. Therefore, graduates will be able to equip themselves with the latest skills needed by industries. In addition, graduates are able to develop their confidence levels, team work skills, communication skills, and the ability to work under pressure and are also will be able to gain on-the-job skills. Therefore, universities should provide students with real life work environments and hands-on learning through on-the-job training programmmes. HEIs need to work closely with industries to improve the marketability and employability of graduates since the employability of the graduates is one of the key performance indicators for higher education. The Malaysian Ministry of Higher Education also stated in its objectives a desire to achieve a level of $75 \%$ employment of graduates within six months of graduation. To ensure the effectiveness of on-the-job training programmes, HEIs must ensure that graduates are assigned to the right companies and the tasks assigned to them are in accordance with their specialization. Also, tasks that are assigned should be beneficial in enhancing their employability skills. If there is a mismatch between a graduate's area of specialization and the tasks assigned to them, graduates would be unable to practice or apply their knowledge and skills in the actual workplace. Thus, the objectives of the on-the-job training programme would not be fulfilled.

\section{REFERENCES}

Abdul Rahman, H., Kwan, C. L., \& Woods, P. C. (1999). Quality function deployment in construction design: application in low-cost housing design. International Journal of Quality \& Reliability Management, 16(6), 591-605.

Akao, Y. (1990). Quality function deployment: integrating customer requirement into product design. Dearborn, MI: Productivity Press.

Akao, Y., \& Mazur, G. H. (2003). The leading edge in QFD: past, present and future. International Journal of Quality \& Reliability Management, 20(1), 20-35.

Azian, H., \& Mun, L. Y. (2011, April 10). English work: top jobs only for those who know the language well. The Star, p. $1 \& 5$.

Bicknell, B. A., \& Bicknell, K. D. (1995). The roadmap to repeatable success. Boca Raton: CRC Press.

Bouchereau, V., \& Rowlands, H. (2000). Methods and techniques to help quality function deployment. Benchmarking: An International Journal, 7(1), 8-19.

Chan, L. K., \& Wu, M. L. (2002). Quality function deployment: a literature review. European Journal of Operational Research, 143(3), 463-497.

Cohen, L. (1995). Quality function deployment: how to make QFD work for you. AddisonWesley: Reading, MA.

Day, R. G. (1993). Quality function deployment. Milwaukee: ASQ Press.

Eureka, W. E., \& Ryan, N. E. (1994). The customer-driven company: managerial perspective on QFD. Dearborn: ASI Press. 
Gonzalez, M. E., Quesada, G., \& Bahill, A. T. (2004). Improving product design using quality function deployment: the school furniture case in developing countries. Quality Engineering, 16(1), 45-56.

Griffin, A., \& Hauser, J.R. (1993). The voice of the customer. Marketing Science, 12(1), 1-27.

Han, S. B., Chen, S. K., Ebrahimpour, M., \& Sodhi, M. S. (2001). A conceptual QFD planning model. International Journal of Quality \& Reliability Management, 18(8), 796-812.

Kumar, A., Antony, J., \& Dhakar, T. S. (2006). Integrating quality function deployment and benchmarking to achieve greater profitability. Benchmarking: An International Journal, 13(3), 290-310.

Lee, S. F., Lo, K. K., Leung, R. F., \& Ko, A. S. O. (2000). Strategy formulation framework for vocational education: integrating SWOT analysis, balanced scorecard, QFD methodology and MBNQA education criteria. Managerial Auditing Journal, 15(8), 407-423.

Lockamy III, A., \& Khurana, A. (1995). Quality function deployment: total quality management for new product design. International Journal of Quality \& Reliability Management, 12(6), 73 84.

Logothetis, N. (2004). Managing for total quality - from Deming to Taguchi and SPC. New Delhi: Prentice-Hall.

Mallon, J. C., \& Mulligan, D. E. (1993). Quality function deployment - a system for meeting customers' needs. Journal of Construction Engineering and Management, 119(3), 516-531.

MOHE (Ministry of Higher Education). (2006). Model pembangunan kemahiran insaniah (soft skills) untuk institusi pengajian tinggi Malaysia. Serdang: Penerbit Universiti Putra Malaysia.

Reeves, C. A., \& Bednar, D. A. (1994). Defining quality: alternatives and implications. Academy of Management Review, 19, 3.

ReVelle, J. B., Moran, J. W., \& Cox, C. A. (1998). The QFD handbook. New York: John Wiley \& Sons.

Zairi, M., \& Youssef, M. A. (1995). Quality function deployment: a main pillar for successful total quality management and product development. International Journal of Quality \& Reliability Management, 12(6), 9-23. 